\title{
超空間化学：分子配列・反応・その場観察
}

\section{Supraspace Chemistry: Molecular Array, Reactions, In-situ Observation}

\author{
東京大学大学院理学系研究科化学専攻 塩谷＼cjkstart光彦* \\ Department of Chemistry, Graduate School of Science, The University of Tokyo
}

Mitsuhiko Shionoya*

Received September 30, 2019; Accepted October 3; Published November 30

\begin{abstract}
Supramolecular self-assembly of a certain number of designer organic/inorganic building blocks by directional interactions such as metal coordination is the basis of elaborate molecular systems. Most molecular architectures are purpose-designed in light of the size, shape, and surface natures of building blocks as well as chemical environments. On the other hand, we have occasionally come across unexpected structures and functions as a result of more complicated self-assembly processes than expected, which have often opened a new frontier in chemistry. We have been focusing on coordination-driven self-assembly directed toward artificial metallo-DNAs, ${ }^{1,2}$ metallo-containers, ${ }^{3,4}$ molecular ball bearings, ${ }^{5}$ molecular gearing systems, ${ }^{6}$ and metal macrocycle frameworks (MMFs). ${ }^{7.8}$ This paper describes supraspace chemistry taking an example of a supramolecular porous crystal, MMFs, which provides a confined nano-space for molecular recognition and transformation.
\end{abstract}

\section{1. はじめに}

有機化学や無機化学のやっかいもの（Komplex）だっ た金属錯体の基礎が作られたのは，ほんの 100 年ほど前 のことである。それ以来，金属錯体の合成法や構造決定 法の進歩により，錯体化学は著しい発展を遂げてきた。 さらに, 約 50 年前のクラウンエーテルの発見をきっかけ に,さまざまなタイプの超分子金属錯体が誕生し, 機能 性材料やバイオ関連化学の発展に大きく寄与している。

筆者は，精密に分子設計された有機配位子とさまざま な金属イオンとを組み合わせることにより，下記に示す 「配列」「空間」「分子機械」「配位アシンメトリー」の視 座から, 独自の超分子金属錯体の構築に力を注いできた。

(1) 配列：一原子から生体高分子までを鋳型とする金 属配列の化学 (金属錯体型人工 DNA 等 ${ }^{1,2}$ )

(2) 空間：ナノサイズの「超空間」構築と分子配列・ 変換制御 (分子カプセル, ${ }^{3,4}$ 多孔性超分子結晶 ${ }^{7,8}$ )

(3) 分子機械 : 分子ギアシステムの構築と回転運動制御 ${ }^{5}$

(4) 配位アシンメトリー：金属中心キラリティーに基づ く非対称配位空間の化学

連絡先著者名 : 塩谷 光彦

連絡先 : 113-0033 東京都文京区本郷 7-3-1

東京大学大学院理学系研究科化学科

Tel: 81-3-5841-8061 Fax: 81-3-5841-8061

Corresponding Author: Mitsuhiko Shionoya

Address: 7-3-1 Hongo, Bunkyo-ku, Tokyo 113-0033, Japan

E-mail: shionoya@chem.s.u-tokyo.ac.jp

Keywords: molecular design, self-assembly, metal-assembled complexes, molecular array, molecular motion, nano-space, molecular recognition, spacespecific reactions
本稿では，これらの中から「超空間」の構築，特に環 状金属錯体の自己集積により構築される多孔性超分子結 晶に焦点を当て,「超空間」に特異的な分子のふるまい について議論したい。

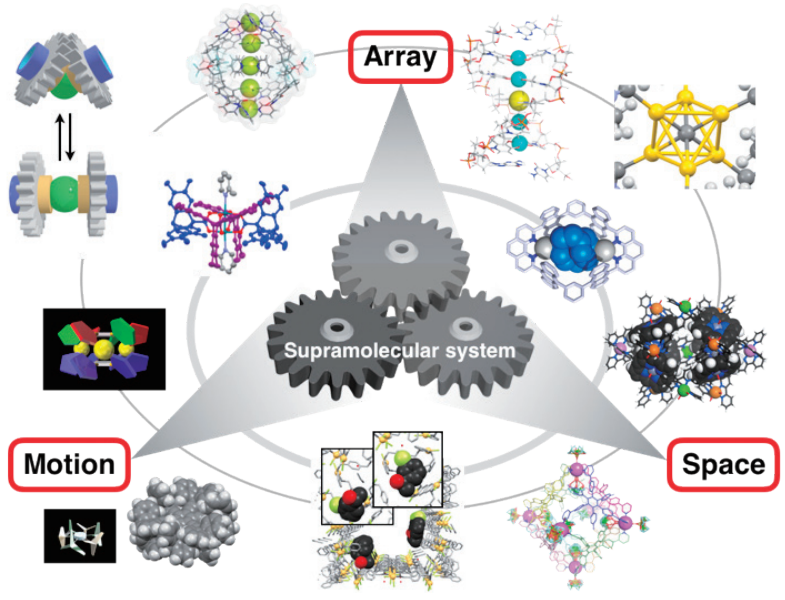

\section{2.「超空間」の構築と機能化}

\section{1.「超空間」とは何か}

複数の構成分子が自己集合することにより分子集合体 の内部や表面近傍に形成されるシナジー機能空間を,「超 空間」と呼ぶことにする。「超空間」の場としての性質 やそのダイナミクスは, 構成分子の立体・表面構造と性 質，構成分子間の相対配置や相互作用に依存し，このよ うな空間に特異的な機能は, 個々の構成分子のみでは通 常実現できない。 
「超空間」の概念に基づいて発展したナノ空間の化学 は, 生命分子の構造や機能を発想の原点としていると 言つても過言ではない。特に, 金属酵素の活性中心がX 線構造解析により次々に決定され，その分子集合体の構 造とシナジー機能の相関を, 天然分子の化学修飾や人工 分子の精密設計により具現化あるいは凌駕しようという アプローチが盛んに行われている。

\section{2.「超空間」を生む多孔性超分子結晶}

多孔性配位高分子 (Porous Coordination Polymer: PCP) または金属 - 有機物構造体 (Metal-Organic Framework: MOF）は，活性炭やゼオライトをはるかに超える大き な表面積を持つ多孔質材料である。これらの結晶は，金 属と有機配位子から成る配位ネットワーク内のナノサイ ズの細孔を有するため，これを利用した，ガス吸着（貯 蔵や分離), センサー, 触媒などに広く用いられている。 これらの三次元構造の情報は $\mathrm{X}$ 線回折測定により得る ことができ, 細孔内に取り込まれた分子・イオンの構造 や吸着・包接特性を知ることができる。また, 配位高分 子の材料となる有機配位子に対して機能付加に必要な官 能基を導入することにより, 設計に基づいて結晶細孔内 を化学修飾ができることも魅力的な特徵の一つである。

これまで, 環サイズ, 細孔形状, 官能基が異なるさま ざまな環状ホスト化合物が発見・合成されてきた。上述 のように, 環状ホスト化合物が自己集積した多孔性超分 子結晶の細孔内への分子・イオンの取り込みにおいて, 環状ホスト化合物の分子 ・イオンの認識能は多孔性結晶 の細孔の機能化における最も重要な因子である。このよ うに, 環状ホスト化合物の分子認識部位が結晶内に配列 されることにより，分子認識部位間の相乗効果に基づく 「超空間」特異的な機能発現が可能となる (Fig. 1)。

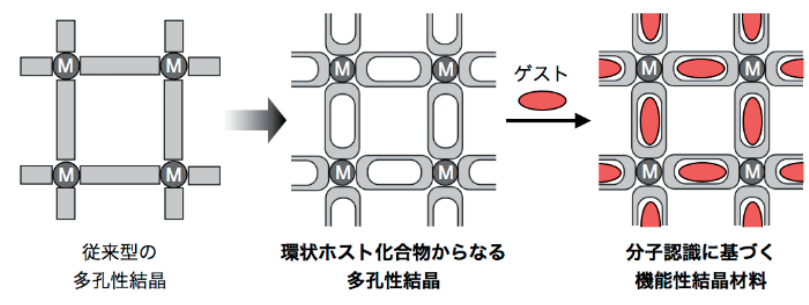

Fig. 1 従来型の多孔性結晶と環状ホスト化合物から成る多孔性超 分子結晶

\section{3. 偶然発見された多孔性超分子結晶: Metal-} Macrocycle Framework (MMF) ${ }^{7,8 a}$

化学の重要な目標の一つは, 分子を自在に設計・合成 する方法を確立することである。化学合成においては, 共有結合を基盤とする有機合成と，さらに非共有結合を 駆使する超分子合成がある。後者は，与えられた化学環 境における複雑な分子の自己集積過程を経るため, 思い
がけない分子集合体構造にめぐり会うことがある。以下 に紹介する多孔性超分子結晶は，まったく別の目的で行 つた研究の中で偶然に発見された産物である。

筆者らは2012 年に, 環状へキサアミン配位子 (L) と 3 当量の $\mathrm{PdCl}_{2}\left(\mathrm{CH}_{3} \mathrm{CN}\right)_{2}$ からラセン型環状三核 $\mathrm{Pd}^{\mathrm{II}}$ 錯体 $\left[\mathrm{Pd}_{3}(\mathbf{L}) \mathrm{Cl}_{6}\right]$ が生成することを報告した。環状錯体 $\left[\mathrm{Pd}_{3}(\mathbf{L})\right.$ $\left.\mathrm{Cl}_{6}\right]$ は，環内の $\mathrm{CH}-\pi$ 相互作用によりラセン構造が誘起 され，そのねじれ方向によって $\boldsymbol{P}$-および $\boldsymbol{M}$ - 異性体が 生成する。また，三つの $\mathrm{Pd}^{\mathrm{II}}$ イオンの相対位置によって syn- および anti- 異性体が生成する（Fig. 2a）。すなわち， (P)-syn, (M)-syn, (P)-anti, (M)-anti の四つの異性体が同 時生成し, さらにこれらが水素結合や $\mathrm{Pd}^{\mathrm{II}}-\mathrm{Pd}^{\mathrm{II}}$ 相互作用 を介して共結晶化することにより，多孔性超分子結晶が 収率よく生成する。得られた多孔性結晶の立体構造は, 単結晶 X 線回折測定により決定され，その環状金属錯 体から構成されることにちなんで, Metal-Macrocycle Framework (MMF) と名付けられた。MMF 結晶は, 1.4 $\mathrm{nm} \times 1.9 \mathrm{~nm}$ 径のナノチャネル構造が平行に配列した， 空隙率約 44\%の多孔性構造を有する (Fig. 2b)。

MMF の最も特筆すべき構造特性は, ナノチャネルを構 成する壁面に, 10 種類の分子認識ポケットが配置されて いることである (Fig. 2c,d)。上述のように, MMF は三核 $\mathrm{Pd}^{\mathrm{II}}$ 環状錯体 $\left[\mathrm{Pd}_{3}(\mathbf{L}) \mathrm{Cl}_{6}\right]$ の四つの異性体 $((\boldsymbol{P})-$ syn, $(\boldsymbol{M})-$
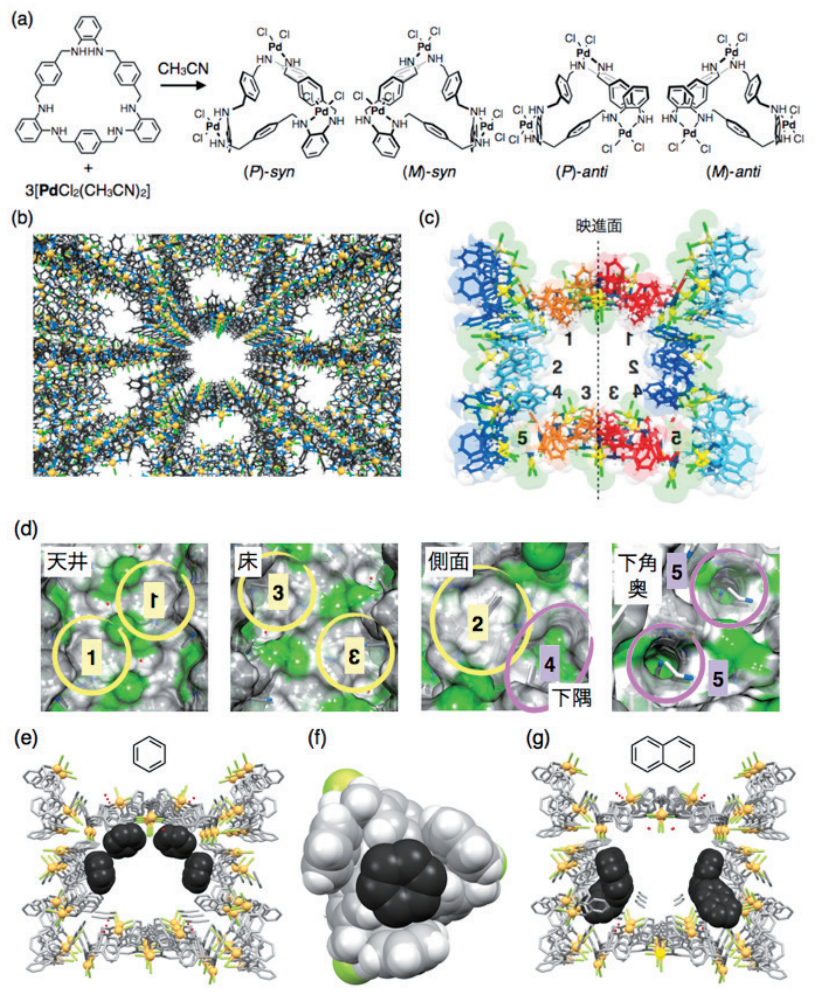

Fig. 2 多孔性超分子結晶 MMF。(a) 環状配位子 (L) の錯体形成に より生成する 4 種類の異性体。(b) 結晶パッキング構造。(c) 細孔 構造と壁面上の 10 種類の分子認識ポケット。(d) 細孔壁面の分子 認識ポケットの構造。(e) ベンゼン分子を捕捉・配列した MMF 細 孔構造。(f) 側面の環状ポケットに捕捉されたベンゼン分子。(g) ナフタレン分子を捕捉・配列した MMF 細孔構造。 
syn, (P)-anti, (M)-anti) から構成される。さらに各異性体 の環の表と裏の面構造は $\mathrm{Pd}^{\mathrm{II}}$ イオンの数により異なるた め，チャネル細孔壁面には最大 8 種類 [4 (異性体数) $\times 2$ (表裏ポケットの数)］の環状構造由来の分子認識ポケッ トが配列される可能性が考えられた。実際，8種類のうち 6 種類のポケットがチャネル壁面に露出し, さらに錯体間 に形成された “間隙”に由来する 4 種類の分子認識ポケ ットも形成される。チャネルの細孔壁面の単位構造あた りに, 5 種類の分子認識ポケット（3 種類が環状錯体由来, 2 種類が錯体間隙由来) がチャネル中心の映進面を挟んで 鏡像異性体対として配列する（合計 10 種類）（Fig. 2c）。

\subsection{MMF 結晶内のゲスト分子認識 7,8a-c}

MMF 結晶内の分子認識ポケットは, 結晶場でさまざ まなゲスト分子を位置選択的に捕捉できる。例えば, べ ンゼンーアセトニトリルの 1:1 混合溶媒に MMF 結晶を 浸漬すると，チャネル壁面の側面ポケットと天井ポケッ トにベンゼン分子が捕捉されることが, 単結晶 X 線回折 測定により明らかになった（Fig. 2e)。具体的には，(M)syn 体および $(\boldsymbol{P})$-syn 体のフェニレンジアミン環に囲まれ た側面ポケットには, ベンゼン環が多点 $\mathrm{CH}-\pi$ 相互作用 を介して“はまり込む”ように捕捉される（Fig. 2f）。こ れに対して, より広い $\pi$ 平面を有するナフタレンやアズ レンの場合は, いずれもベンゼンの場合とは異なり, 側 面ポケットと下隅ポケットに捕捉される (Fig. $2 \mathrm{~g}$ )。こ の結果は, MMF チャネル壁面の各分子認識ポケットが, ゲスト分子のサイズや形状を識別できることを示してい る。また, 分子認識ポケットはベンゼン環の置換様式を 識別できる。例えば, ジブロモベンゼンの異性体の場合, $o$ - 異性体はナフタレンと同様に側面および下隅ポケット に， $m$ - 異性体はベンゼンと同じ側面および天井ポケット に, $p$ - 異性体は下隅ポケットのみに, それぞれ位置選択 的に捕捉される (Fig. 3a,b)。さらに, $m$-および $p$ - 異性
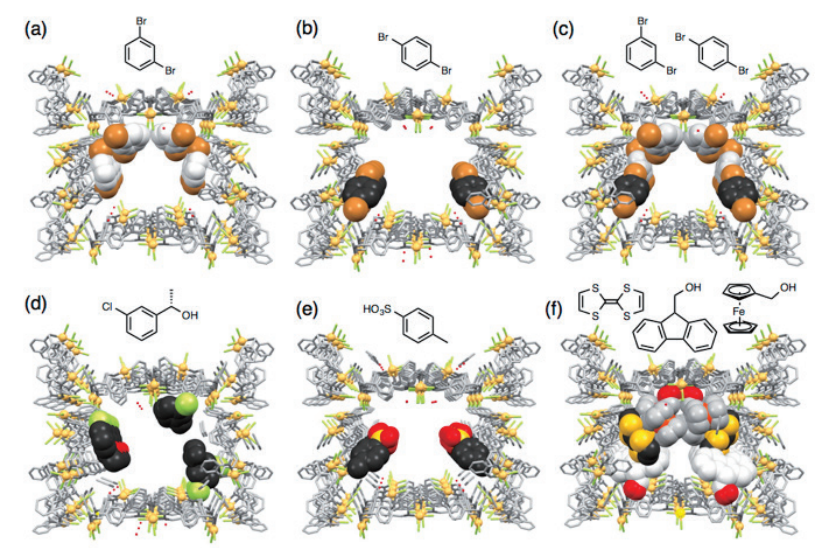

Fig. $3 \mathrm{MMF}$ 細孔内の各種ゲスト分子の配列構造。(a) $m$ - ジブロ モベンゼン, (b) $p$ - ジブロモベンゼン, (c) $m$ - ジブロモベンゼンと p- ジブロモベンゼン, (d) (1S)-1-(3- クロロフェニル ) エタノール, (e) p-トルエンスルホン酸, (f) TTF とヒドロキシメチルフェロセ ン, 9- フルオレニルメタノール
体を同時に用いた場合，それぞれの異性体単独の場合と 同じポケットに包接され，これらの異性体がチャネル内 で位置選択的に同時配列することを示した（Fig. 3c)。

MMF 細孔内の分子認識ポケットは, ゲスト分子のサ イズや形状を識別できるだけでなく，各ポケットがラセ ン構造由来のキラリティーを有するため, 光学活性なゲ スト分子をキラル識別することもできる。例えば，光 学活性な (1S)-1-(3-クロロフェニル)エタノールは, 細 孔内の両側面にある $(\boldsymbol{M})$-syn 体および $(\boldsymbol{P})$-syn 体のうち, (M)-syn 体ポケットのみにジアステレオ選択的に結合す ることが単結晶 X 線回折測定より明らかにされた（Fig. 3d)。一方, 天井および下隅ポケットの場合, $(\boldsymbol{P})$ - 体由 来のポケットのみにゲスト分子が捕捉される。また，当 然予想されるように，(1R)-1-(3-クロロフェニル ) エ夕 ノールは, 他方の鏡像異性体ポケットにのみ捕捉される。 このように, MMF 結晶を構成するラセン型環状錯体の 構造特性を活かすことにより，キラルなナノ空間を構築 することが可能である。

MMF 細孔表面上の分子配列は，チャネル内への触媒 固定や官能基配列を可能にする。例えば，典型的な酸触 媒であるベンゼンスルホン酸や $p$-トルエンスルホン酸 は，チャネル壁面の下隅ポケットに位置選択的に結合す る（Fig. 3e）。スルホン酸基はチャネル空間に露出して おり, 酸触媒反応やプロトン伝導などへの展開が期待さ れている。また, スルホン酸類以外にも, 優れた電子ド ナー化合物であるテトラチアフルバレン（TTF）や, 酸 化還元活性な有機金属錯体であるフェロセン誘導体，広 い $\pi$ 平面を有するフルオレン誘導体も，チャネル表面に 位置選択的に配列する。例えば，ヒドロキシメチルフエ ロセンや9- フルオレニルメタノールは, 各々のヒドロキ シメチル基が MMF 細孔表面のアミノ基やクロロ基と水 素結合を介して結合するため, 水酸基が分子配列のアン カーとして働く。また, 異なる種類のゲスト分子の配列 においては, 協同効果や競争効果が見られる。例えば, TTF 単独の場合, MMF 細孔表面への吸着は観測されな いが，TTF をヒドロキシメチルフェロセンあるいは 9- フ ルオレニルメタノールと混合して用いると, 協同効果に より 2 種類のゲスト分子がチャネルに取り込まれ, 位置 選択的に特定のポケットに捕捉される。さらに，3 種類 のゲスト分子, TTF, ヒドロキシメチルフェロセン，9フルオレニルメタノールをすべて混合した場合, これら がチャネル内に位置選択的に同時配列することが単結晶 X 線回折測定により確認できた（Fig. 3f)。実際に得られ たゲストの同時配列構造には, さまざまなゲスト間相互 作用が観測され，分子配列における協同効果もしくは競 合関係が明らかにされた。このような異種分子配列法は, 酵素の活性中心に見られるような, 複数の異なる官能基 が協同的に働く反応場の構築に適用できるであろう。 
2.5. MMF 結晶内の分子配列過程のその場観察 $8 d$

分子配列に基づく自己組織化現象を詳細に明らかにす ることは，固体表面や界面の分子のふるまいを知る上で 重要な課題である。上記のチャネル内の分子配列実験で は, 多くの場合, ゲスト分子捕捉後も単結晶性が保たれ る。筆者らはこの事を利用して, MMF 細孔壁面での分 子配列過程を単結晶 $\mathrm{X}$ 線回折測定で経時追跡すること に挑戦した。その結果, ゲスト分子が細孔表面の分子認 識ポケットに配列するプロセスをスナップショット撮影 することに成功した。

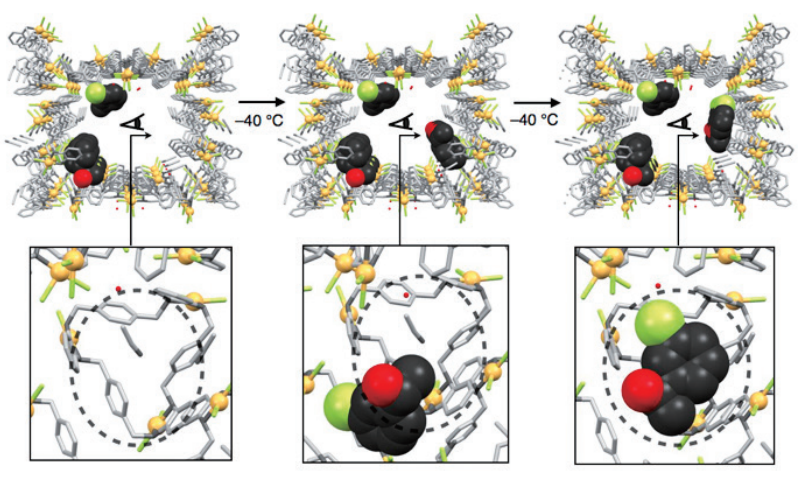

Fig. 4 MMF 細孔内に取り込まれたゲスト分子 (1R)-1-(3- クロロフ エニル ) エタノールの段階的配列挙動の単結晶 X 線スナップショ ット観察。下段の枠内は, 各段階における $(\boldsymbol{P})$-syn 体ポケット周 辺の拡大図。点線で囲まれた部分はそのポケットを示している。

まず，光学活性ゲスト分子である (1R)-1-(3-クロロフ エニル) エタノールのアセトニトリル溶液に MMF 結晶 を通常より短時間 (5 分以内) 浸したのち, 取り出し た結晶を $-180{ }^{\circ} \mathrm{C}$ 急冷して単結晶 $\mathrm{X}$ 線回折測定を行う と, ゲスト分子が最終的に結合するチャネル側面の $(\boldsymbol{P})-$ syn 体ポケットにはゲスト分子は結合しておらず，アセ トニトリル分子のみが観測される（Fig. 4: left）。なお, $-180^{\circ} \mathrm{C}$ とう低温下では, チャネル内の分子配列はほと

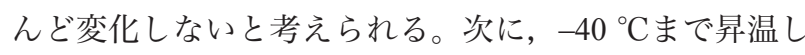
30 分間静置したのち, 再び $-180{ }^{\circ} \mathrm{C}$ 急冷して X 線回 折測定を行うと, $-40{ }^{\circ} \mathrm{C}$ とう比較的高い温度では分子 配列過程が少し進行し, $(\boldsymbol{P})-$ syn 体ポケットのすぐ隣に ゲスト分子が捕捉されている構造が観察される（Fig. 4: center)。再び $-40^{\circ} \mathrm{C}$ 昇温し, さらに分子配列過程を進 行させると, ゲスト分子は移動して $(\boldsymbol{P})$-syn 体ポケット 内に収まり平衡に達する (Fig. 4: right)。これらの結果は, ゲスト分子が最終位置に収まる前に, 隣の分子認識サイ トへ過渡的に結合するという, 段階的な分子配列過程が 存在していることを示す。このような単結晶 X 線回折 による過渡的プロセスの “可視化” は, 自己組織化の分 子レベルの理解に大きく貢献すると期待される。
2.6. MMF 結晶が形成する「超空間」に特異な反応の 発見 ${ }^{8 f, 9}$

MMF 結晶が有する「超空間」は，分子認識部位や $\mathrm{Pd}^{\mathrm{II}}$ 中心を有するため, 高効率・高選択的反応場への展 開が期待される。これまで, ナノチャネルの開口部のサ イズに着目したサイズ特異的反応 ${ }^{8 \mathrm{f}}$ や, ナノチャネル内 に配列している $\mathrm{Pd}^{\mathrm{II}}$ 中心を利用した光触媒反応 ${ }^{8 \mathrm{~g}}$ を報告 した。本稿では，後者の反応について紹介する。

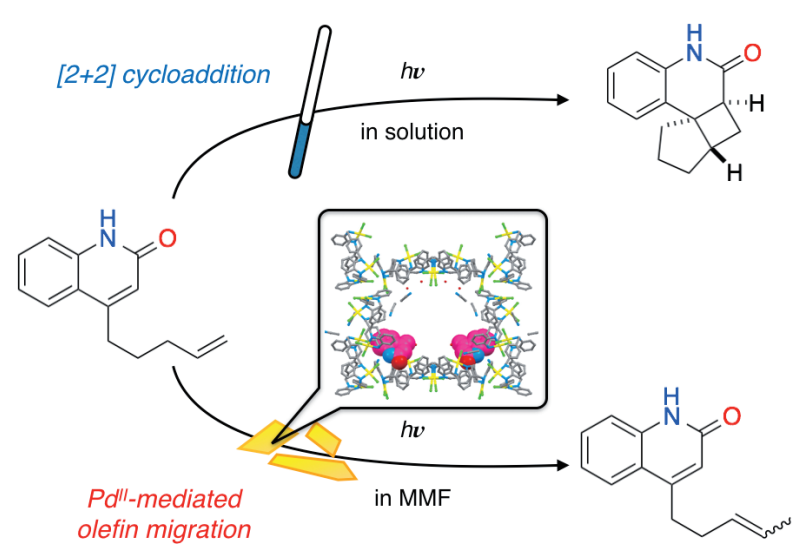

Fig. 5 光照射下の二つの異なる反応経路 : [2+2] 付加環化反応（溶 液中）とオレフィン移動反応（MMF 中）。

キノリノン骨格を有する 1,6- ジエンは，溶液中で光 照射すると, 分子内環化付加体を与えることが知られて いる（Fig. 5)。ところが，この 1,6-ジエンを細孔内に取 り込んだ MMF 結晶を光照射すると, 分子内環化付加反 応は全く起こらず，代わりにオレフィン移動反応が進行 することが明らかになった。基質分子が細孔壁面に吸着 されることで環化反応に必要なコンフォメーションを取 る過程が阻害され, MMF 骨格自体が光遮蔽効果を持つ ことにより分子内環化付加が抑制されたと考えられる。 一方で, 光照射された $\mathrm{MMF}$ では $\mathrm{Pd}^{\mathrm{II}}$ に配位した $\mathrm{Cl}$ 配 位子が一部解離することが単結晶 $\mathrm{X}$ 線回折測定や量子 化学計算より示唆されたことから, Cl が解離したあと に生じた細孔壁面上の $\mathrm{Pd}^{\mathrm{II}}$ 配位部位がオレフィン移動反 応の触媒反応場を与えたと考えられる。孤立した「超空 間」では, 通常のバルク溶液内とは異なる, 予想外の化 学反応が起こりうることを示しており, 新反応の発見や 反応の効率・選択性の精密制御につながると期待される。

\section{3. まとめ}

本稿では，環状ホスト化合物を構成成分とする多孔性 超分子結晶 MMF について, 合成法, 構造解析, 分子認 識能，分子配列過程，空間特異的反応に焦点を絞って説 明した。MMF 結晶では, それを構成する環状ホスト化 合物が明確な分子認識部位として機能するため, 従来型 
の多孔性結晶にはない優れた分子認識能や分子配列能を 示す。異種の環状ホスト構造を同一結晶細孔内に組み込 むことにより，異種環状ホスト化合物が形成する「超空 間」の協同効果が発揮される。その結果, 異種の複数分 子の同時配列や光学活性なキラルゲスト分子のジアステ レオ選択的配列, 細孔壁面における段階的な分子配列過 程のその場観察が可能になった。さらに，通常のバルク 溶液中では起こらない「超空間」に特異な反応は，ナノ 空間における基質の表面吸着と溶媒和， $\mathrm{Pd}^{\mathrm{II}}$ 中心の光触 媒サイクルにより起こりうることが，実験および量子化 学計算により明らかになった。今後は, キラルな空間に 分子認識ポケットと触媒部位が緻密に配列された, 多機 能性人工酵素の開発が重要な課題である。

\section{謝辞}

本稿で述べた「超空間」に関する研究は, 当研究室の 田代省平准教授が中心となり, 主に当時大学院生の窪田 亮博士，梅木勉氏，米澤拓孝博士により精力的に行われ ました。また, X 線構造解析については城始勇博士およ び佐藤寛泰博士（リガク）に，理論計算については江原 正博教授 (分子科学研究所) に大変お世話になりました。 この場をお借りして，心から感謝申し上げます。

\section{文献}

1 For reviews, a) K. Tanaka, M. Shionoya, Coord. Chem. Rev. 2007, 251, 2732-2742; b) G. H. Clever, M. Shionoya, Coord. Chem. Rev. 2010, 254, 2391-2402; c) E. Stulz, G. H. Clever, M. Shionoya, C. Mao, Chem. Soc. Rev. 2011, 40, 5633-5635; d) Y. Takezawa, M. Shionoya, Acc. Chem. Res. 2012, 45, 2066-2076; e) G. H. Clever, M. Shionoya in Interplay between Metal Ions and Nucleic Acids, Vol. 10 of Metal Ions in Life Sciences (Eds.: A. Sigel, H. Sigel, R. K. O. Sigel), Springer Science + Business B. V., Dordrecht, 2012, pp. 264-294; f) G. H. Clever, M. Shionoya in Metallofoldamers: Supramolecular Architectures from Helicates to Biomimetics (Eds.: G. Maayan, M. Arbrecht, Wiley, Chichester, 2013, Chapter 9, pp. 303-332; g) Y. Takezawa, M. Shionoya in Biomimetics Bioinspired Materials, Mechanics, and Dynamics, Vol. 1 of Handbook of Biomimetics and Bioinspiration, World Scientific Publishing, Singapore, 2014, pp. 217-245; h) Y. Takezawa, J.-L. A. Duprey, M. Shionoya in DNA in Supramolecular Chemistry and Nanotechnology (Eds.: E. Stulz, G. H. Clever), John Wiley \& Sons, 2015, pp. 65-75; i) Y. Takezawa, J. Müller, M. Shionoya, Chem. Lett. 2017, 46, 622-633; j) Y. Takezawa, J. Müller, M. Shionoya in Comprehensive Supramolecular Chemistry II, Elsevier, Oxford, 2017, pp. 259-293.

2 a) K. Tanaka, M. Shionoya, J. Org. Chem. 1999, 64, 5002-5003; b) M. Shionoya, K. Tanaka, Bull. Chem. Soc. Jpn. 2000, 73, 1945-1954; c) H. Cao, K. Tanaka, M. Shionoya, Chem. Pharm. Bull. 2000, 48, 1745-1748; d) K. Tanaka, M. Tasaka, H. Cao, M. Shionoya, Eur. J. Pharm. Sci. 2000, 13, 77-83; e) M. Tasaka, K. Tanaka, M. Shiro, M. Shionoya, Supramol. Chem. 2001,
13, 671-675; f) K. Tanaka, M. Tasaka, H. Cao, M. Shionoya, Supramol. Chem. 2002, 14, 255-261; g) K. Tanaka, Y. Yamada, M. Shionoya, J. Am. Chem. Soc. 2002, 124, 8802-8803; h) K. Tanaka, A. Tengeiji, T. Kato, N. Toyama, M. Shiro, M. Shionoya, J. Am. Chem. Soc. 2002, 124, 12494-12498; i) S. Aketani, K. Tanaka, K. Yamamoto, A. Ishihama, H. Cao, A. Tengeiji, S. Hiraoka, M. Shiro, M. Shionoya, J. Med. Chem. 2002, 45, 5594-5603; j) S. Aketani, K. Tanaka, K. Yamamoto, A. Ishihama, H. Cao, A. Tengeiji, M. Shionoya, Eur. J. Pharm. Sci. 2003, 20, 43-51; k) K. Tanaka, A. Tengeiji, T. Kato, N. Toyama, M. Shionoya, Science 2003, 299, 1212-1213; 1) M. Shionoya, K. Tanaka, Curr. Opin. Chem. Biol. 2004, 8, 592-597; m) K. Tanaka, M. Shionoya, Chem. Lett. 2006, 35, 694-699; n) K. Tanaka, G. H. Clever, Y. Takezawa, Y. Yamada, C. Kaul, M. Shionoya, T. Carell, Nat. Nanotechnol. 2006, 1, 190-194; o) Y. Takezawa, K. Tanaka, M. Yori, S. Tashiro, S. Motoo, M. Shionoya, J. Org. Chem. 2008, 73, 6092-6098; p) Y. Takezawa, W. Maeda, K. Tanaka. M. Shionoya, Angew. Chem., Int. Ed. 2009, 48, 1081-1084; q) S. Liu, G. H. Clever, Y. Takezawa, M. Kaneko, K. Tanaka, X. Guo, M. Shionoya, Angew. Chem., Int. Ed. 2011, 50, 8886-8890; r) J.-L. Duprey, Y. Takezawa, M. Shionoya, Angew. Chem., Int. Ed. 2013, 52, 1212-1216; s) Y. Takezawa, K. Nishiyama, T. Mashima, M. Katahira, M. Shionoya, Chem. Eur. J. 2015, 21, 14713-14716; t) T. Kobayashi, Y. Takezawa, A, Sakamoto, M. Shionoya, Chem. Commun. 2016, 52, 3762-3765; u) Y. Takezawa, S. Yoneda, J.-L. Duprey, T. Nakama, M. Shionoya, Chem. Sci. 2016, 7, 3006-3010; v) Y. Takezawa, T. Kobayashi, M. Shionoya, Int. J. Mol. Sci. 2016, 17, 906; w) K. Nishiyama, Y. Takezawa, M. Shionoya, Inorg. Chim. Acta 2016, 452, 176-180. For reviews, a) T. Nakamura, H. Ube, M. Shionoya, Chem. Lett. 2013, 42, 328-334; b) L.-J. Chen, H.-B. Yang, M. Shionoya, Chem. Soc. Rev. 2017, 46, 2555-2576.

4 a) S. Hiraoka, T. Yi, M. Shiro, M. Shionoya, J. Am. Chem. Soc. 2002, 124, 14510-14511; b) S. Hiraoka, K. Harano, M. Shiro, M. Shionoya, Angew. Chem., Int. Ed. 2005, 44, 2727-2731; c) S. Hiraoka, K. Harano, M. Shiro, Y. Ozawa, N. Yasuda, K. Toriumi, M. Shionoya, Angew. Chem., Int. Ed. 2006, 45, 6488-6491; d) S. Hiraoka, K. Tanaka. M. Shionoya, J. Am. Chem. Soc. 2006, 128, 13038-13039; e) K. Harano, S. Hiraoka, M. Shionoya, J. Am. Chem. Soc. 2007, 129, 5300-5301; f) S. Hiraoka, Y. Sakata, M. Shionoya, J. Am. Chem. Soc. 2008, 130, 10058-10059; g) S. Hiraoka, K. Harano, M. Shiro, M. Shionoya, J. Am. Chem. Soc. 2008, 130, 14368-14369; h) S. Hiraoka, M. Goda, M. Shionoya, $J$. Am. Chem. Soc. 2009, 131, 4592-4593; i) S. Hiraoka, K. Harano, T. Nakamura, M. Shiro, M. Shionoya, Angew. Chem., Int. Ed. 2009, 48, 7006-7009; j) G. H. Clever, S. Tashiro, M. Shionoya, Angew. Chem., Int. Ed. 2009, 48, 7010-7012; k) S. Hiraoka, Y, Yamauchi, R. Arakane, M. Shionoya, J. Am. Chem. Soc. 2009, 131, 11646-11647; 1) S. Hiraoka, M. Kiyokawa, M. Shionoya, Angew. Chem., Int. Ed. 2010, 49, 138-143; m) G. H. Clever, S. Tashiro, M. Shionoya, J. Am. Chem. Soc. 2010, 132, 9973-9975; n) Y. Sakata, S. Hiraoka, M. Shionoya, Chem. Eur. J. 2010, 16, 3316-3325; o) G. H. Clever, M. Shionoya, Chem. Eur. J. 2010, 16 , 11792-11796; p) S. Hiraoka, T. Nakamura, M. Shiro, M. Shionoya, J. Am. Chem. Soc. 2010, 132, 13223-13225; q) G. H. Clever, W. Kawamura, M. Shionoya, Inorg. Chem. 2011, 50, 4689-4691; r) G. H. Clever, W. Kawamura, S. Tashiro, M. Shiro, M. Shionoya, Angew. Chem., Int. Ed. 2012, 51, 2606-2609; s) S. Tashiro, K. Matsuoka, A. Minoda, M. Shionoya, Angew. Chem., Int. Ed. 2012, 51, 13123-13127; t) M. Kuritani, S. Tashiro, M. Shionoya, Inorg. Chem. 2012, 51, 1508-1515; u) M. Han, J. Hey, W. Kawamura, D. 
Stalke, M. Shionoya, G. H. Clever, Inorg. Chem. 2012, 51, $9574-$ 9576; v) T. Nakamura, H. Ube, M. Shiro, M. Shionoya, Angew. Chem., Int. Ed. 2013, 52, 720-723; w) T. Nakamura, H. Ube, M. Shionoya, Angew. Chem., Int. Ed. 2013, 52, 12096-12100; x) T. Nakamura, H. Ube, R. Miyake, M. Shionoya, J. Am. Chem. Soc. 2013, 135, 18790-18793; y) K. Omoto, S. Tashiro, M. Kuritani, M. Shionoya, J. Am. Chem. Soc. 2014, 136, 17946-17949; z) S. Tashiro, M. Yamada, M. Shionoya, Angew. Chem., Int. Ed. 2015, 54, 5351-5354; a') K. Omoto, S. Tashiro, M. Shionoya, Z. Anorg. Allg. Chem. 2015, 641, 2056-2059; b') M. Shimada, Y. Yamanoi, T. Ohto, S. Pham, R. Yamada, H. Tada, K. Omoto, S. Tashiro, M. Shionoya, M. Hattori, L. Jimura, S. Hayashi, H. Koike, M. Iwamura, K. Nozaki, H. Nishihara, J. Am. Chem. Soc. 2017, 139, 11214-11221; c') H. Ube, K. Endo, H. Sato, M. Shionoya, J. Am. Chem. Soc. 2019, 131, 10384-10389; d') K. Omoto, S. Tashiro, M. Shionoya, Chem. Sci. 2019, 10, 7172-7176.

5 a) S. Hiraoka, K. Harano, T. Tanaka, M. Shiro, M. Shionoya, Angew. Chem., Int. Ed. 2003, 42, 5182-5185; b) S. Hiraoka, M. Shiro, M. Shionoya, J. Am. Chem. Soc. 2004, 126, 1214-1218; c) S. Hiraoka, K. Hirata, M. Shionoya, Angew. Chem., Int. Ed. 2004, 43, 3814-3818; d) S. Hiraoka, E. Okuno, T. Tanaka, M. Shiro, M.
Shionoya, J. Am. Chem. Soc. 2008, 130, 9089-9098; e) S. Hiraoka, Y. Hisanaga, M. Shiro, M. Shionoya, Angew. Chem., Int. Ed. 2010, 49, 1669-1673; f) E. Okuno, S. Hiraoka, M. Shionoya, Dalton Trans. 2010, 39, 4107-4116.

6 a) K. Sanada, H. Ube, M. Shionoya, J. Am. Chem. Soc. 2016, 138, 2945-2948; b) H. Ube, Y. Yasuda, H. Sato, M. Shionoya, Nat. Commun. 2017, 8, 14296; c) H. Ube, R. Yamada, J. Ishida, H. Sato, M. Shiro, M. Shionoya, J. Am. Chem. Soc. 2017, 139, 16470-16473.

7 For a review, S. Tashiro, M. Shionoya, Bull. Chem. Soc. Jpn. 2014, $87,643-654$.

8 a) S. Tashiro, R. Kubota, M. Shionoya, J. Am. Chem. Soc. 2012 , 134, 2461-2464; b) R. Kubota, S. Tashiro, T. Umeki, M. Shionoya, Supramol. Chem. 2012, 24, 867-877; c) S. Tashiro, T. Umeki, R. Kubota, M. Shionoya, Angew. Chem., Int. Ed. 2014, 53, 83108315 ; d) R. Kubota, S. Tashiro, M. Shiro, M. Shionoya, Nat. Chem. 2014, 6, 913-918; e) R. Kubota, S. Tashiro, M. Shionoya, Chem. Sci. 2016, 7, 2217-2221; f) S. Tashiro, H. Yonezawa, R. Kubota, T. Umeki, M. Shionoya, Chem. Commun. 2016, 52, 7657-7660; g) H. Yonezawa, S. Tashiro, T. Shiraogawa, M. Ehara, R. Shimada, T. Ozawa, M. Shionoya, J. Am. Chem. Soc. 2018, 140, 16610-16614.

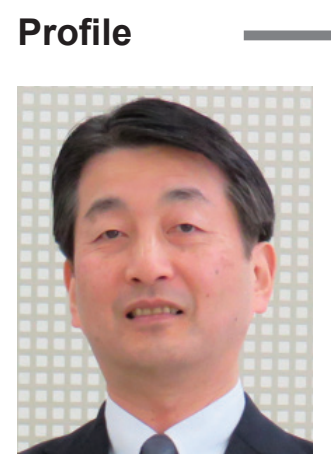

塩谷 光彦

東京大学大学院理学系研究科教授 薬学博士

[学歴] 1982 年 東京大学薬学部製薬化学科卒業, 1984 年 東京大学大学院薬学系研究科修士課 程修了, 1986 年 東京大学大学院薬学系研究科博士課程中退, 1990 年広島大学薬学博士。

[職歴］1986 年 広島大学医学部総合薬学科助手, 1988 年 分子科学研究所助手, 1988 年 広島 大学医学部総合薬学科助手, 1991 年 広島大学医学部総合薬学科講師, 1994 年 広島大学医学 部総合薬学科助教授, 1995 年 分子科学研究所教授, 1999 年 東京大学大学院理学系研究科教 授，現在に至る。2003 年 Louis Pasteur 大学客員教授，2007 年 LMU Münich 客員教授，2014 年 Strasbourg 大学客員教授。この間, 日本学術振興会学術システム研究センター主任研究 員, 日本学術会議連携会員, 日本化学会誌 Bull. Chem. Soc. Jpn. 編集幹事, 日本化学会速報誌 Chemistry Letters 編集委員長，米国化学会Acc. Chem. Res. 編集諮問委員会委員等を歴任。 [受賞歷］ 2007 年 日本化学会学術賞，2007 年 井上学術賞。2008 年 Louis Pasteur 大学メダル, 2016 年 文部科学大臣表彰科学技術賞，2018 年 錯体化学会賞，2020 年 Izatt-Christensen Award [専門] 生物無機化学, 超分子化学 